\title{
Exilio, insilio, cárcel y violencia: 1948-1952
}

German Chacón-Araya

Académico

Mario Oliva-Medina

Investigador

Universidad Nacional de Costa Rica

El que milita ardientemente en un bando político, o en un bando filosófico, escribirá su libro de historia con tinta del bando. Mas la verdad, como el sol, ilumina la tierra a través de las nubes. Y con las mismas manos que escribe el error, va escribiendo la verdad. José Martí, 8 de marzo de 1882.

\section{Resumen}

En este ensayo buscamos acercarnos a la suerte que corrieron miles de costarricenses durante el inicio del año 1948 hasta 1952. Dicho periodo está marcado por el comienzo de la represión abierta de carácter político contra los adversarios del autodenominado Ejército de Liberación Nacional, que ingresó a la capital a fines de abril de 1948, y hasta el al año de 1952, fecha límite cuando la mayor parte de los exiliados políticos regre-

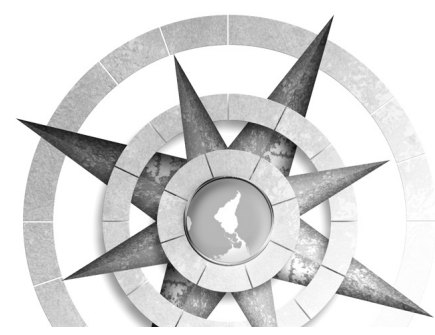

saron al país producto de nuevas condiciones democráticas que se estaban gestando.

Palabras clave: exilio costarricense, guerra civil de 1948, insilio, Cátedra del Exilio, Temas de Nuestra América
Abstract
In this essay we aim to approach the fate of thousands of Costa Ricans from beginning of 1948 to 1952 . This period is marked by the launch of an open political repression against the adversaries of the self-proclaimed Ejército de Liberación Nacional [Army of National Liberation], that entered the capital city at the end of April 1948. This analysis goes up to the year 1952, when most of the political exiles returned to the country as a result of new democratic conditions. 
Keywords: Costa Rican exile, Costa Rican Civil War of 1948, insilio, Exile Research Group, Temas de Nuestra América

La Guerra civil costarricense de 1948 cuenta con una abundante y especializada bibliografía donde se aborda dicho acontecimiento. Copiosos aparecen los textos dedicados a la memoria de los actores más relevantes, así como sobre el proceso que llevó al enfrentamiento de sectores sociales por hacer prevalecer sus proyectos políticos y sociales para el país. Mucho menor atención han recibido aspectos como la represión, la cárcel, el exilio, el insilio, el destierro y la emigración, sufridos por una parte considerable de la población costarricense. En otras palabras los vencidos en esa contienda no tienen historia o simplemente fue silenciada por los vencedores. Es en la últimas dos décadas cuando aparecen estudios importantes que contribuyen a llenar dicho vacío. ${ }^{1}$ Aun así, creemos que existen

1 Véanse las obras de: Oscar Aguilar Bugarelli, Costa Rica y sus hechos políticos de 1948. Problemática de una década, San José de Costa Rica, EUNED, 2004; Mercedes Muñoz. Niñas y Niños del 48 escriben, San José, Costa Rica, Editorial de la Universidad de Costa Rica, 2004; Rodolfo Cerdas Cruz, La otra cara del 48:Guerra Fría y movimiento obrero en Costa Rica 1945-1952. San José, Costa Rica, EUNED, 1998; David Díaz Arias, Crisis social y Memorias en lucha. Guerra civil en Costa Rica. 19401948. San José de Costa Rica, Editorial de la Universidad de Costa Rica, 2015; Víctor Hugo Acuña Ortega. Conflicto y reforma en Costa Rica: 19401949. San José, Costa Rica, UNED, 1992; Manuel, Solís Avendaño, La institucionalidad ajena: serias lagunas de conocimiento sobre el fenómeno en su conjunto.

Pretendemos en este ensayo acercarnos a la suerte que corrieron decenas, cientos y miles de costarricenses durante el inicio del año 1948 hasta 1952; delimitación arbitraria y marcada, principalmente, por el inicio de la represión abierta de carácter político contra los adversarios del autodenominado Ejército de Liberación Nacional, que ingresó a la capital a fines de abril de 1948, mientras el año de 1952 fue la fecha límite en que la mayor parte de los desterrados, exiliados políticos han regresado al país, producto de nuevas condiciones democráticas que se están gestando. Resulta paradójico que sean precisamente los comunistas en circunstancias de clandestinidad y sectores muy amplios de la población que de modo cotidiano los que van construyendo esa democracia perdida y secuestrada.

\footnotetext{
"los años cuarenta y el fin de siglo. San José, Costa Rica, Editorial de la Universidad de Costa Rica, 2006; y también de Solís Avendaño. Memoria descartada y sufrimiento invisibilizado, San José de Costa Rica, Editorial de la Universidad de Costa Rica, 2013; Manuel Rojas Bolaños. Lucha Social y Guerra Civil en Costa Rica, 1940-1948. San José de Costa Rica, Editorial Alma Mater 1986; Iván Molina Jiménez y Fabrice Lehoucq, "Urnas de los inesperado”, San José de Costa Rica, Editorial de la Universidad de Costa Rica, 1999; y también de Molina Jiménez. Moradas y discursos, Heredia, Costa Rica, EUNA, 2010; Ignacio Dobles Oropeza y Vilma Leandro Zúñiga, Militantes, San José de Costa Rica, Editorial de la Universidad de Costa Rica, 2005.
} 
Una perspectiva de análisis que se sugiere en el estudio del exilio es superar la mirada nacional y ubicar el tema en dimensiones más regionales, transnacionales o aún continentales; de ningún modo el exilio costarricense puede ser ni siquiera visualizado y mucho menos comprendido desde enfoques nacionales se debe considerar su dimensión regional, como intentaremos mostrar.

Mario Sznajder y Luis Roniger definen el destierro o exilio político como un mecanismo de exclusión institucional -no el único-, mediante el cual alguien involucrado en la política y la vida pública, o alguien al que quienes detentan el poder perciben de ese modo, es forzado o presionado a abandonar su país de origen o lugar de residencia, imposibilitado de regresar hasta que no haya una modificación de las circunstancias políticas. ${ }^{2}$ Este concepto amplio y flexible permite en nuestro caso acercarnos al exilio costarricense y, más específicamente, comunista y calderonista, no sólo en México sino en varios países de Centroamérica, con expresiones particulares.

La primera delimitación que debemos hacer es que el fenómeno de exclusión institucional, desarrollado por los vencedores de la Guerra Civil de 1948,

2 Mario Sznajder y Luis Roniger, La política del destierro y el exilio en América Latina, México, FCE, 2013, p, 31. mostró que el exilio no es un asunto de élites políticas; por el contrario, se desenvuelve masivamente. Sin embargo, si nos atenemos a las fuentes disponibles hasta ahora, el acercamiento a esas masas de población que se vieron obligadas por las condiciones políticas, sociales o económicas a cruzar las fronteras del país, es poco, no está disponible o sencillamente no existe.

En este último sentido, la historia oral proporciona una riqueza enorme, siempre y cuando distingamos que "El testimonio es reconstrucción del recuerdo. La historia es construcción en base al documento," como precisara Pierre Vilar. ${ }^{3}$ Un modo de obtener información al respecto, considerando que una parte abundante de los protagonistas de la contienda ha fallecido o se encuentra en edad avanzada; es la entrevista a sus familiares, hermanos, hijos u otros.

Es importante destacar que los registros escritos oficiales, por obvias razones, son también escasos, como bien lo reseña Moreno Fraginalis:

Puede afirmarse que la casi totalidad de los documentos con que trabaja el historiador se originaron en las clases dominantes. Ahora bien, en un lógico

3 Pierre Vilar, Metodología histórica de la guerra y revolución española, Barcelona, Editorial Fontamara, 1980 , p. 70. 
proceso defensivo estas clases dominantes han ido depurando sus documentos, borrando como delincuentes- las huellas de sus pasos y dejándonos, como fuentes históricas, un material previamente seleccionado y con el cual sólo puede llegarse a ciertas conclusiones. ${ }^{4}$

Efectivamente, para hacer historia de los vencidos hay que superar estos escollos que señala el historiador cubano. Por tanto, no podemos hoy despreciar ningún indicio que nos permita acercarnos a estos procesos y explorar de manera creativa nuevas fuentes: hemos recurrido a los archivos diplomáticos mexicanos, correspondencia, así como a los periódicos clandestinos de orden comunista, como Trabajo, y a algunas entrevistas que nos permitan fundamentar pistas. Para este estudio, son importantes los discurso de época y, principalmente, textos autobiográficos, biografías, memorias, géneros narrativos -como novela, cuentos y poesía- y la plástica, que se convierten en material de primer orden para el rastreo de la vida en sus diversas manifestaciones, no sólo políticas y culturales, sino de lo que nosotros llamamos sociabilidad, entendida esta última como lo propone el historiador francés Maurice Agulhon cuando sugiere poner atención a los lu-

4 Moreno Fraginalis, La historia como arma, Barcelona, Editorial Crítica, 1983, p. 17. gares de sociabilidad informal que permiten a hombres y a mujeres la ocasión de encontrarse, de discutir y de opinar sobre la política. ${ }^{5}$

Las tensiones entre las viejas generaciones de liberales y la nueva generación surgida en las primeras décadas del siglo $\mathrm{XX}$, las cuales pretenden imponer un proyecto de país más solidario, que llevará al conflicto bélico entre los diversos grupos. Como parte de una pugna por el poder, en su afán por conseguirlo, estos grupos se dan a la tarea de fabricar un nuevo caudillismo de corte populista. ${ }^{6}$

Ya en el año de 1947, se asomaba como práctica diaria la violencia verbal desarrollada por el periodista y candidato a la presidencia, Otilio Ulate, como bien explica el sociólogo Manuel Solís:

Ulate trabajo la hostilidad hasta el fanatismo. Su principal instrumento fue la palabra. Con ella dibujo una imagen tenebrosa de sus oponentes y esculpió sentencias que resonarán a la distancia de los años: si es calderonista no le compre, no le hable, no le venda [...]

5 Véase Maurice Agulhon, El círculo burgués, Argentina, Editorial Siglo XXI Editores, p. 23 y siguientes.

6 Díaz Arias, op. cit., pp. 7-62. 
Con el viento de la Guerra Fría a su favor, predico como un hecho cierto que el Gobierno estaba en manos de los comunistas. Hizo de Calderón Guardia [...] el más decisivo factor de penetración del comunismo.

La fantasía del asesinato del padre fomentaba y justificaba la agresividad. Sobre esto se montó Ulate. El enemigo despreciable que dibujo con sus palabras debía ser expulsado de la comunidad, y despojado de los lazos que hacían posible su existencia[...] a la vez, denuncio la traición de Calderón Guardia "a su amigo" y protector de antes, rechazo con vehemencia que Cortéz hubiese tenido simpatía por los nazis. Lo sacó de la esquina donde lo habían puesto los republicanos, los comunistas, los centristas y el mismo [...] A la vez, denuncio la traición de Calderón Guardia a su "amigo" y protector de antes, rechazo con vehemencia que Cortéz hubiese tenido simpatía por los nazis. Lo saco de la esquina donde lo habían puesto lo republicanos, los comunistas, los centristas y el mismo $[\ldots]^{7}$
La situación de guerra civil en la que se encontraba el país durante 1948, trajo consigo situaciones violentas: se sucedieron asesinatos, desapariciones, despojos de bienes, ultraje de viviendas y personas, lo que casi convirtió a país en un campo de concentración. Elsa Sáenz Ferreto recordaba así aquellos días, cuando apenas era una adolecente: "Todavía se oían en las calles de San José, aislados disparos de vencedores y vencidos. Todavía las pasiones ardían al rojo vivo: odio, rencor, venganza, desenfrenada embriaguez de victoria; dolor y humillación: rechinar de dientes y explosión de risas: era el final del aspecto militar de la revolución".

El 24 de abril de 1948, las fuerzas armadas figueristas entraron a la ciudad de San José, y así finalizó un mes y medio del alzamiento contra el gobierno de Picado, apoyado por los denominados caldero-comunistas. Se abre un periodo de represión brutal contra los perdedores del conflicto que perturba las más hondas raíces democráticas que el país construía desde hacía al menos tres décadas, particularmente en los años cuarenta, trastornando, así, la vida y la convivencia de la ciudadanía en su vida intima y colectiva. Obsérvese este relato de Sáenz Ferreto:
7 M. Solis Avendaño, La institucionalidad ajena..., pp. 191-225.
8 Elsa Sáenz Ferreto, Otras voces del 48, Heredia, EUNA. 1998, p. 24. 
Pactos político-militares; amagos de intervención extranjera, ajusticiamientos, allanamientos de viviendas, en la casa de mi abuela, donde vivía ella con mis tres tías solteras, los soldados enchuchados, rifle al hombro y bayoneta calada, revisaron "en busca de armas", toda la casa, hasta el hermoso y humeante fogón. Todas estas cosas llenaban la vida diaria de los costarricenses del hoy casi olvidado, y sin embargo, inolvidable, año $1948 .{ }^{9}$

Narraciones como ésta son frecuentes en toda la literatura crítica producida en los últimos años en Costa Rica, dedicada a recuperar la memoria o, mejor dicho, la otra memoria de aquellos que quedaron excluidos de todo registro oficial. Se trata de procesos que conmovieron la vida cotidiana de las familias con lo que ello implica en el conjunto de la sociedad.

Es importante observar que ése es un periodo de posguerra, en el que en lo internacional ya tiene lugar una nueva oleada anticomunista que se denominó la Guerra Fría, caracterizada por la persecución y represión contra todos los movimientos nacionalistas, antiimperialistas, democráticos y revolucionarios, calificados bajo el denominador

$9 \quad$ Ibid. común de "comunistas", que es impuesto a los gobiernos en Latinoamérica por la potencia norteamericana que sale fortalecida y hegemónica de la Segunda Guerra Mundial. Como lo ha analizado el historiador David Díaz sobre la base de legajos del Partido Vanguardia Popular y de otra documentación, es presumible la intervención de la Embajada de Estados Unidos en apoyo a los grupos opositores a los comunistas desde antes de la Guerra Civil de 1948, así como la traición y deslealtad de sus aliados. ${ }^{10}$

Las secuelas del antes, durante y después de la guerra llevaron a que muchos hombres y mujeres terminaran recluidos en el Hospital Psiquiátrico Chapuí, dice el sociólogo Manuel Solís en su análisis de los expedientes de esa institución. En Costa Rica, los médicos del hospital habrían absorbido "toda la discusión "sobre las sintomatologías derivadas de las acciones bélicas vividas en la Segunda Guerra Mundial, tales como sudoraciones, parálisis, huidas despavoridas y dificultades para hablar, entre otros muchos síntomas, por lo que durante y después de la Guerra Civil de 1948 los médicos nacionales empezaron a diagnosticar una gran cantidad de casos que, a su juicio, calificaban como pacientes postraumáticos de los eventos en el antes, durante y después del 48.

10 Ibid., pp. 345-350. 
Muchos de los casos tienen que ver con la pérdida del ser amado y la pérdida del empleo particularmente relevante para los funcionarios públicos, pérdida de bienes y el hostigamiento de parte de los vencedores. Los médicos indican que sus pacientes, padecen "neurosis de guerra", diagnóstico que podría en algunos casos no ser correcto. Indica el autor:

Los tribunales sometieron a los perseguidos a todo tipo de interrogatorios y a pruebas de descargo donde en la mayoría de los casos citaron a los triunfadores como testigos para afectar los bienes o la libertad del adversario, en algunos casos tiempo después de 6 meses o más los Tribunales dictan sentencia, para lo que ya habrían establecido un estribillo, "Suspender el acto de los bienes familiares, no sin antes establecer que no cabían reclamaciones por daños o perjuicios" [...] la razón dada es: la situación imperante cuando se dio la ley de intervención, era tal la desconfianza que imponía aclaraciones para casi todos los servidores públicos de los regímenes anteriores. ${ }^{11}$
Los estudios sobre el exilio pasada la guerra no tienen carta de ciudadanía en la historiografía costarricense, aspecto que no atañe a este país, sino que se convierte en una problemática centroamericana, caribeña y continental, si pensamos en la geografía donde fueron a parar decenas, centena y hasta miles de costarricenses, cantidades con las cuales coinciden todos los testimonios de la época y que resultan difíciles de rastrear de otro modo. José Albertazzi Avendaño en su libro La tragedia de Costa Rica, reflexiona:

El exilio era un término que los costarricenses conocíamos en el diccionario, pero que jamás habíamos conjugado en la realidad [...] Bajo el actual régimen de terror, unos con pasaporte otros sin él, fugitivos por las montañas -casi todos en las más lamentables condiciones económicas porque al negárseles la patria, se les intervinieron sus bienes- el calderonismo se acogió al exilio en el cual se exponía a pasar las penas negras, pero se sentía libre de persecución, de la prisión, de las torturas y del fusilamiento; Venezuela, Colombia, Panamá, Nicaragua, vieron llegar a centenares y a miles de expatriados costarricenses en busca de refugio. ${ }^{12}$
11 M. Solís Avendaño, Memoria descartada y [...] pp. 190-194.
12 José Albertazzi Avendaño, "La tragedia en Costa Rica”, en Macarena Barahona (edit.), Nuevos 
Entre los países que más costarricenses recibieron tenemos Panamá y Nicaragua; hacia este último, es probable que cruzaran la frontera miles, como asegura Oscar Bakit; Panamá pudo ser país receptor de muchos obreros bananeros, mientras que en Guatemala el proceso político dirigido por el entonces presidente Juan José Arévalo favoreció este tipo de emigración y exilio. El investigador Albertazzi Avendaño nos dice al respecto: "Fui el primer expatriado que llegó a Guatemala. Muy pocos días después llegó Rodrigo Montoya; parecía que nosotros hubiéramos iniciado un éxodo de compatriotas decentes hacia esa república [...]". ${ }^{13}$ Días después, se sumaron decenas de costarricenses, quienes fundaron asociaciones de carácter solidario y político para mantener discusiones y acciones sobre la situación de Costa Rica y el resto del continente junto con expatriados de gobiernos de facto, sobre todo de Centroamérica y el Cono Sur, al que se sumaban españoles.

Un joven militante de Vanguardia Popular, en aquellos años, Antonio Barrantes Roldán (Ameba $)^{14}$ nos dijo recientemente:

documentos de 1948 Los proscritos. San José de Costa Rica, ECR., 2015, pp. 48 y 49.

13 Ibid., 103

14 Antonio Barrantes Roldán nació en 1922, según la cedula, "pero él dice que nació en 1924". Su padre fue de los fundadores del Partido Comunista, era carpintero y fue baleado en 1934, cuando nuestro entrevistado tenía escasos 10 años. Ese
Aquellos días fueron muy duros y de mucha violencia, yo era un mozalbete [...] Como yo era muy grande y bueno para los puños me vincule a los grupos que defendíamos los actos públicos, es decir a las mal llamadas brigadas de choque, en la guerra yo anduve por todo lado junto a los contingentes de la juventud del partido, como chofer, miliciano y mensajero, estuve en ecos del 56 nuestra emisora, junto a Eduardo Mora, ${ }^{15}$ él había estado en México comenzando estudios en la UNAM, y en labores de seguimiento a la Legión Caribe, cuando la guerra comenzó se vino y traía unas armas para las milicias comunistas.

día me marco para el resto de la vida; me convertí en comunista. A mi casa llegaban los trabajadores del gremio de carpinteros comunistas a discutir; ellos estaban organizados en células, y no conocía a otras células, realmente no todo el mundo podía ser militante, eso sólo por méritos. Repartía el periódico y volantes; me hice marxista estudiando con Carmen Lira y otros compañeros. Recuerdo el discurso de Lombardo Toledano por más de 2 horas y nadie se movía, ni chistaba, de esa manera aprendíamos sobre la problemática social y la lucha obrera."

15 Para ampliar detalles sobre ese momento en particular de la Guerra y de las acciones en la que participó Eduardo y Barrantes véase el capítulo La Guerra Civil de 1948, en Eduardo Mora, 70 años de militancia comunista. Editorial Juicentro, 2000, pp. 131-159. 
Un día el partido decidió que por mi seguridad debía salir del país y me mandaron el tiquete con un compañero venezolano de Mérida quien me acompañó hasta Caracas, con poca plata en los bolsillos (en esos días salimos miles, principalmente para Centroamérica y el Caribe), después llegaron otros compañeros, como el químico Fernando Chávez Molina, miembro de la dirección política del PVP, de quien Manuel, decía que era un genio, a los días contacté con el PC Venezolano y me dediqué a pintar, como chofer y otros trabajos, fueron días muy duros, vivía pobremente y alejado de los míos, temeroso y esperando mi retorno, poco salía a alguna reunión y algún cine hasta que el partido me indicó que podía regresar, algunos años después.

De igual modo, fue masivo el insilio como fenómeno social totalmente descuidado por la historiografía nacional. Se trata de cientos de miles de perseguidos que se ocultaron o se fugaron a zonas alejadas de los centros urbanos, preferentemente a las montañas, con el agravante de los peligros y penalidades de esas zonas inhóspitas. Según recuerda doña Flora Desanti Araya, a sus 87 años:
Para esa época cuando estalló la guerra civil tenía 20 años, con una hija de meses, mi padre muerto de una peritonitis porque el tren del Pacífico tardó más de lo esperado en llegar a San José, debido a los problemas políticos de la época, con su esposo militante comunista en Nicaragua, y ella escondida: "Varios días después de terminada la Guerra, una noche apareció Oscar y salimos para Orotina, cuando Oscar ${ }^{16}$ y Caliche nos vinieron a dejar adonde un pariente en Marichal, aquello era terrible, los perros salían a nuestro paso, la gente gritaba: ahí van los comunistas, recuerdo que en la ciudad los mismos pulperos allá por barrio Cuba, donde vivíamos, y a los que toda la vida les habíamos compra-

16 Oscar Alvarado Rojas nació en 1924 y murió a los 76 años. A la edad de 9 años manejaba el carro que les dejó el papá a su muerte para repartir pan, en la ciudad de Grecia. Fue militante del Partido Vanguardia Popular. Era bueno con los puños y vivía cerca de la casa de Manuel Mora Valverde por el Ferrocarril del Pacífico. Fue el chofer que llevó a Manuel a Ochomogo, a la reunión con Figueres. Sus hermanas, de militancia calderonista, se desempeñaron como improvisadas aeromozas en los aviones que el gobierno usaba para trasladar tropas y milicianos a diferentes puntos del país, al igual que muchas mujeres que ayudaron como enfermeras, costureras, haciendo las famosas cobijas de los denominados mariachis*, cocineras, mensajeras, y en muchas actividades propias de una campaña militar.

N.d.E: mariachi se denominaba a los simpatizantes del partido Calderonista) 
do, nos denunciaban con las patrullas de Figueres, y estas nos despedazaban la casa buscando armas y a nuestros parientes, no había casi que comer, nadie nos vendía, nadie nos daba trabajo. Oscar y su hermano salieron hacia Nicaragua, nos dejaron escondidas al ver la situación que se sucedía, a los pocos días mi hermano me recogió y me llevó para Golfito, la mayor parte del tiempo a lomo de mula y en lancha, esto porque los vecinos nos habían denunciado.

Recuerdo que a Oscar y a su hermano Caliche les fue muy mal en Nicaragua, por tener ideas comunistas y como pudieron se regresaron. Oscar mandó un telegrama a Golfito, para esos días mi hermano habría comprado una cazadora barcaza, era el primer vehículo para llevar pasajeros en esas lejanas tierras. Mi hermano habló con la persona encargada del traslado de la cazadora y le dijo que había contratado a un peón y chofer para que le ayudara y así regresó Oscar varios meses después de que me dejara, vino a desempeñarse como chofer y ayudante en la cazadora, fueron días muy duros, pese a la buena voluntad de la familia. ${ }^{17}$

17 Flora Desanti Araya nació en Orotina, provincia de Alajuela, Costa Rica, en el año de 1928. Fue hija de Zoila Araya y Horacio Desanti, hijo de inmigrante francés. Entrevistada en julio del 2016.
En los últimos años, la historiografía nacional ha puesto atención a esta memoria histórica, lo que permite recrear procesos sobre la condición humana atendiendo escenarios más cercanos, más íntimos, como el familiar. Un libro ejemplar en esta dirección es Las niñas y los niños del 48, donde los relatos se nos presentan como un arcoiris, porque ellos nacieron en las familias que militaban en uno y otro bando hasta aquellos que trataron de mantenerse neutrales y fueron envueltos sin proponérselo en la dinámica de la guerra.

Son relatos que se mueven entre el temor y la esperanza, del perseguido, del sufrimiento de los empleados públicos que perdían sus trabajos, de ángeles con rifles, los niños de la guerra cumpliendo misiones en los frentes, la muerte y la vida, el acecho del hambre, de la familia separada, las escaramuzas, la violación al domicilio, los abusos, las lágrimas y el corazón roto, las bombas y el zigzagueo de las ametralladoras, aviones y uniformes, por citar sólo algunas de las anotaciones de esas niñas y niños.

Dentro de éstos, se halla aquel de la madre proletaria comunista, que leía en las sombras de la noche, el periódico de su partido a su hijo, murmurándole cómo se producían las diferencias de clase, mientras él recuerda cómo esa mujer 
operaria de un taller de costuras del mercado central producía bellezas artesanales para los burgueses, iba a escondidas con él a los mítines del Partido Vanguardia Popular (PVP) a escuchar a Manuel Mora, a sabiendas de que si sus patrones la veían la despedirían por comunista. ${ }^{18}$

Cuenta otro testigo de los horrores de la época: "[...] papá quedo con 'nervios' para toda la vida y a veces, cuando estábamos en el corredor por la tarde, de pronto se metía a la casa a esperar que pasara 'fulano de tal' [...] era un miedo sin razón de que la gente lo atacara de pronto[...] tampoco se permitió nunca a mamá, a mí hermano y a mi participar abiertamente en política[...]"19

Aparejado a lo anterior, comunistas y calderonistas sufrieron la detención arbitraria y la cárcel; los números más conservadores hablan de unas 3 mil personas detenidas en cárceles comunes y las típicas comandancias de policías en todos los pueblos del país. Se detenía a los calderonistas y vanguardistas, hombres y mujeres, según Albertazzi: “a las mujeres les cortaban sus cabelleras [...] o las rapaban con la máquina hasta el número cero a las que carecían de ellas, antes de internarlas en las prisiones". ${ }^{20}$

18 M. Muñoz, op. cit., pp. 80-82.

19 Ibid., p., 560.

$20 \quad$ Ibid., p 47
Instalada en el poder la Junta de Gobierno presidida por Figueres, el Partido Vanguardia Popular fue declarado ilegal, la Confederación de Trabajadores de Costa Rica (CTCR) disuelta, lo mismo que sus sindicatos; centenares de dirigentes y militantes de base, así como excombatientes, fueron encarcelados y miles despedidos de sus trabajos, sin pago de prestaciones; los maestros calderonistas y comunistas, sobre todo en el Valle Central, fueron cesados de sus trabajos y sustituidos por personal afín de los vencedores. No hubo familia costarricense que no fuera movida de una u otra manera por la violencia desatada en esos años.

El terror se articula desde arriba hacia abajo. Rodolfo Cerdas sintetiza este proceso:

[...] no más llegar al poder, la Junta de Gobierno emitió el decreto ley N. ${ }^{\circ} 105$ que declara ilegal el comunismo, punibles sus actividades y disueltas sus organizaciones, independientemente del nombre que adoptaran. Más tarde, la disposición adquiría carta constitucional al introducirse por mayoría en la Asamblea Constituyente el párrafo $2^{\circ} \mathrm{del}$ artículo 98, que prohibía "la organización y funcionamiento de partidos que, por sus medios de 
acción, programas ideológicos y vinculaciones internacionales, atenten contra la soberanía de Costa Rica. ${ }^{21}$

Mientras, el historiador Gerardo Contreras da cuenta de otra arbitrariedad de los vencedores: el 17 de diciembre de 1948 la Junta Fundadora de la Segunda República emitió el decreto ley No 306, el cual reza: [...] se consideran despedidos de los cargos, puestos o funciones que desempeñen al servicio del Estado, de sus instituciones autónomas o semiautónomas todas aquellas personas de reconocida afiliación 'calderonista o comunista', este mismo decreto deja sin efectos los artículos 29, 30 y 31 del Código de Trabajo para efecto del pago de prestaciones legales. ${ }^{22}$

La persecución y el encierro a la actividad de la movilización social estrecha el cerco de libertades de los sectores populares durante el gobierno de Otilio Ulate, poco cambiaron las cosas. Este marco de legalidad de la violencia permite a los vencedores actuar con toda impunidad sobre los bienes y las personas, sucediéndose uno tras otro atropello y violación de los derechos más elementales de la ciudadanía ahora etiquetada por sus ideales o preferencias políticas.

21 R. Cerdas, op. cit., p. 49.

22 Gerardo Contreras, Vivencias del PVP, San José de Costa Rica, Ediciones Perro Azul, 2008, p. 118.
Se crean los Tribunales de Sanciones Inmediatas y los Tribunales de Probidad, para perseguir y condenar sin escrúpulos a los ciudadanos; del mismo modo operan los Tribunales de Probidad, que pretendían investigar defraudaciones al fisco y el reintegro de las sumas de dinero de tales defraudaciones a la hacienda pública; así muchos ciudadanos y familias, principalmente calderonistas, fueron despojados de sus bienes y les confiscaron sus cuentas.

Observemos más de cerca estos Tribunales de Sanciones Específicas. En uno de tantos expedientes que se abrieron durante el año 48, Francisco de Paula Amador Sibaja, quien era Agente Fiscal, expuso que se cometieron, durante la Huelga de Brazos Caídos y postrimerías del régimen anterior, hechos delictuosos de varias naturalezas como saqueos, merodeo (hurto de ganado, café, leche en gran escala), homicidios, torturas, flagelaciones, ultrajes, en daño de la ciudadanía oposicionista y de mujeres y niños. Y agrega: "[...] es innegable la participación criminal en el desarrollo y producción de los hechos arriba descritos de los señores Calderón, Rafael y Francisco. Manuel Mora Valverde, René Picado, Juan Tavío, Manuel Rodríguez Torra (SIC), Federico Volio González, Alfredo Garrido Conejo, Rodrigo Perera, Julio López Masegoza y de todos aquellos que como 
consecuencia de las investigaciones resulten responsables". 23

Como se puede desprender de estas líneas, la lista de delitos cometidos por los arriba mencionados era abundante y grave, (todos enemigos de los vencedores y altos dirigentes políticos). Desde luego que argucias como estas de carácter legal no podían llegar muy lejos por lo difícil de aportar las pruebas, pues ninguno de los imputados se encontraba en el país para emprender una defensa si cabía el caso o para hacer cumplir las supuestas contravenciones. Un año más tarde se ordena la suspensión de la causa por falta de requisitos de ley.

Meses antes, en julio de 1948, el Tribunal de Sanciones Inmediatas abrió causa por sedición a un grupo considerable de ciudadanos de filiación comunista en su mayoría y a otros tantos calderonistas, todos ellos ya en la cárcel o en vías de estarlo. El expediente judicial contiene las relaciones de hechos que da cabida a esos juicios masivos; se trata de verdaderos archivos de la vergüenza autoritaria o, como hemos dicho anteriormente, de una construcción institucional que permite operar el terror en buena parte de los ciudadanos del país. La Junta Fundadora de la Segunda República

23 Archivo Nacional, R. 1660, folio 1 y siguientes.
[...] prohíbe la organización o funcionamiento de partidos políticos que por sus programas, medios de acción, vinculaciones o antecedentes se opongan al régimen de Gobierno representativo y democrático de la República, o que atentan contra la soberanía nacional'. Y aún más, el artículo 7 de ese mismo Decreto establece literalmente: 'Declárese comprendido expresamente en la prohibición del artículo primero el Partido Vanguardia Popular'. ${ }^{24}$

Dicho decreto de ley es un edicto contrario a toda convivencia pacífica y raya con cualquier interpretación de un régimen democrático y representativo; por el contrario, se trata de una imposición y límites de tono dictatorial para ejercer con toda la fuerza de la ley en contra de los opositores del gobierno. Significativo resulta de estas medidas que el PVP queda declarado fuera de la ley; sus máximos dirigentes, expuestos ante esta medida extrema, son detenidos, sacados de sus casas delante de sus familias y llevados en vehículos militares a la Penitenciaría Central y otros lugares similares por toda la geografía nacional. Ellos son: Arnoldo Ferreto Segura, Adolfo Braña Roza, Carlos Luis Sáenz Elizondo, Manuel Moscoa Barrantes,

24 Ibid. 
Luis Carballo Corrales, Rodolfo Guzmán Rodríguez, Enrique Conde Conde, Fernando Cháves Molina, Carlos Escalante Vega, Álvaro Montero Vega, Víctor Cordero Segura, Jaime Cerdas Mora, Carlos Luis Fallas Sibaja, Federico Picado Sáenz, Ricardo Pérez Méndez, Rigoberto Álvarez Maroto y Luis González González. A estos nombres se agrega una treintena de personas que fueron arrestadas o llamada para interrogatorios y acusaciones de sedición. ${ }^{25}$

En el periódico clandestino Trabajo, correspondiente a julio de 1948, número 6 , se publicó un extracto del recurso de inconstitucionalidad del decreto elaborado por Jaime Cerdas y demás dirigentes comunistas que se encontraban en la cárcel:

[...] el Tribunal de Sanciones inmediatas es un organismo integrado y organizado por facciosos de los que detentan el poder, creado exclusivamente -como reza cínicamente el propio decreto ley que le dio nacimiento- para perseguir a los llamados

25 Paralelo a estas detenciones el 2 de junio de 1948 se dio el Decreto Ley núm. 41, sobre defraudaciones al fisco, oficina de la Propiedad Intervenida y Tribunal de Probidad. En ese decreto, después de una serie de señalamientos y dictados, se insertó la primera lista de personas a las que se intervinieron sus bienes. Esta primera lista contenía 209 personas, entre físicas y jurídicas. caldero-comunistas, con motivo de las quejas de los que antes fueron llamados oposicionistas y hoy son oficialistas. Es un Tribunal Especial, para determinadas causas, de un partido para perseguir a otro partido; no de jueces sino de verdugos.

Es un tribunal contrario a la Constitución, vigente en parte, y contrario a todas las tradiciones de nuestra república. ${ }^{26}$

El decreto era contradictorio con la legislación vigente y violaba las garantías nacionales individuales que la Constitución establece en varios de sus pasajes, como el principio de que "todo hombre es igual ante la ley"; los caldero-comunistas son desiguales al crearse un tribunal especial, y no tribunales comunes. Era un decreto que se aplicaba retroactivamente; y el otro argumento es que la Constitución establece el derecho de reunión para ocuparse de asuntos políticos sin censura. Por tanto, se impugna por inconstitucional el decreto que los convierte en reos y acusados de sedición.

En esa primera lista de detenidos, es notoria la presencia de la totalidad de la alta dirigencia de Vanguardia Popular,

26 Trabajo, 6 de julio de 1948, pp. 1-4. 
con la excepción de su secretario general Manuel Mora Valverde, quien había alcanzado el asilo político primero en la Embajada de México, e inmediatamente pasa a ser exiliado en el país azteca, junto con Carmen Lira y Judith Ferreto, la primera en estado de salud grave y la segunda en tareas de enfermera de la escritora.

Los interrogatorios iniciaron el 21 de julio, estando la mayor parte de ellos en la cárcel de varones de San José (Penitenciaria Central) y las mujeres detenidas en El Buen Pastor. Luis Carballo Corrales, abogado y reconocido dirigente comunista, se negó a declarar ante el Tribunal, por lo que se ordenó castigó, aplicándosele el reglamento de la prisión. No sabemos qué tipo de escarmientos tuvo que soportar: probablemente aislamiento y otro tipo de privaciones propias de estos casos. Los otros presos políticos fueron interrogados de modo muy sencillo y directo. Por ejemplo: Instructor: ¿Sabe o presume por qué se le recibe declaración indagatoria? Indiciado: Supongo que es por mi filiación política.

La pregunta central era, por parte del instructor: ¿Es usted dirigente o militante del Partido Vanguardia Popular? Rodolfo Cerdas, Arnoldo Ferreto y otros contestaban que sí pertenecían a esa agrupación y eran dirigentes; otros simplemente argumentaron que, al permanecer desde hacía varias semanas en prisión y disuelto el partido por orden constitucional, era contradictorio pertenecer a una agrupación disuelta por ley.

Arnoldo Ferreto, secretario de la agrupación política, a la pregunta de si era actualmente vanguardista, a contestó impugnando el carácter capcioso de la pregunta, y aclara: "nadie tiene derecho a marcarme normas para mi pensamiento político y para mi actividad como ciudadano, que creo que tengo derecho de pensar como me dé la gana y como ciudadano a militar políticamente como me lo marca mi conciencia”. ${ }^{27}$ Además, agregó:

Rechazó el cargo de sedición por las siguientes razones: primero que he estado detenido en la Penitenciaria desde hace más de un mes y desde luego durante los días que hace de haber sido promulgado el decreto que proscribe al PVP y por lo visto se nos pretende aplicar con carácter retroactivo. Segundo: Porque el PVP inscribió su programa y sus estatutos ante el Registro Electoral habiendo recibido su aprobación de su entonces Director, ahora Ministro de este

27 Archivo Nacional, R 1660, f. 3. 
Gobierno, Licenciado Benjamín Odio. Que al aprobar el señor Odio nuestro programa y nuestros estatutos, tanto él como el Tribunal Nacional Electoral, del que forma parte el actual presidente de la Corte Suprema de Justicia, declararon que nuestro partido no se oponía a los principios democráticos en que siempre se ha asentado nuestra República. Que por lo demás nuestro Partido ha considerado antes y debe considerar ahora que no procede ningún camino subversivo para restaurar la democracia en Costa Rica. ${ }^{28}$

No pueden ser más esclarecedoras estas confesiones del máximo dirigente político del PVP en ese momento en el país; el PVP actuaba en total armonía con el proceso democrático costarricense, hasta que un decreto lo dejó fuera de la ley, y son los mismos que de manera constitucional aceptaron el proyecto comunista en el espacio de libertad establecido y son esos mismos quienes le quitaron los derechos. El otro aspecto notorio de estas declaraciones de Ferreto es que, estando en la cárcel junto con un grupo considerable de camaradas y los dirigentes máximos de dicha agrupación, rechazó los métodos subversivos

28 Ibid. para el restablecimiento de la democracia, y ése es el camino que adoptan los comunistas durante el final de los años cincuenta y las décadas siguientes.

El resto de los indiciados contestaron de manera esquemática a las preguntas sin comprometer la situación por la que atravesaban. El presidio de la dirigencia comunista probablemente permitió articular sus actividades y recomponer la organización del Partido, incluido su periódico Trabajo. Es precisamente en esas hojas poligrafiadas de tamaño oficio largo, en papel transparente (cebolla), donde encontramos una de las declaraciones más particulares del pensamiento comunista en circunstancias tan adversas referidas al tema del exilio y donde expresan en carta que se dirige al ministro de Justicia con toda su fuerza y claridad lo siguiente:

En relación con nuestro extrañamiento del país, hemos considerado: 1. Que somos costarricenses, o residentes responsables de hogares costarricenses. 2. Que no hay motivo justo alguno que autorice a nadie para echarnos de nuestra patria y de nuestros hogares. 3. Que los militares no son subordinados del actual gobierno y son factor incontrolado que no garantiza la seguridad personal 
de los ciudadanos, por el bien de Costa Rica, creemos conveniente que se limite a los militares y no a los ciudadanos. 4. Que si la situación del país es tan grave como para que el gobierno no pueda garantizar la vida ni la libertad de los costarricenses. Nosotros reclamamos el privilegio de sufrir con el resto de nuestros compatriotas el martirio a que se someta a nuestra patria y a nuestro pueblo. Por todo lo cual respondemos: que nos quedaremos en el país, y no haremos (vemos) ninguna posibilidad para que continúe ocultándose al continente $\mathrm{y}$ al mundo la situación real que existe dentro de nuestro país. Que, ya en libertad es posible que algunos de nuestros compañeros lleguen a pensar en abandonar el país por razones personales, pero en ningún concepto con el auxilio oficial de quienes los persiguen en su vida, su libertad y en hacienda. Por los detenidos de Vanguardia Popular. Luis Carba1lo Corrales. ${ }^{29}$

En consecuencia, este grupo de comunistas decidió en primera instancia quedarse en el país, dejando, así, la posibilidad del destierro y el exilio para aquellos que

29 Trabajo, N.o.1, mayo de 1948, p. 4. consideren que ésa es la vía, esto último limitado a sus propias posibilidades y sin el apoyo o ayuda oficial.

La carta anteriormente transcrita, fue publicada solamente por el periódico clandestino Trabajo, en su edición número 5, de julio de 1948. De manera premonitoria, en ese mismo periódico, en la nota "El camino del crimen", se lee qué va ocurrir con los comunistas en su futuro inmediato:

Ante la negativa de los dirigentes vanguardistas a abandonar por las buenas el país, tres caminos le quedan según La Nación del 13 de julio, le queda al gobierno: el destierro forzoso, el encarcelamiento de por vida, o la libertad para esos presos políticos.

Un cuarto camino queda, que no menciona La Nación, pero al cual se refirió el Ministro de Justicia al enviar a nuestros camaradas un emisario con su mensaje de muerte: el Ejército Nacional los asesinará si no abandonan el país.

Varios de estos detenidos buscaron la salida del país apenas fueron liberados de la cárcel, en el mes de septiembre de 1948, como sucedió con: Carlos Luis Sáez quien viajó a Panamá para 
integrarse al cuerpo docente de la Escuela Normal de Santiago Veragua; y Rodolfo Guzmán, quien se dirigió a México. Otros fueron desplazados al destierro y a camino de la muerte y, según esta nota del periódico, también se cumplió con el crimen de dirigentes políticos, como fue el conocido asesinato del "Codo del diablo", que no fue el único.

La cárcel vivida y sufrida por la dirigencia y militancia caldero-comunistas se prolongó por tres meses largos hasta que se produce la Amnistía General el 15 de septiembre de 1948, aunque algunos volvieron a ser encarcelados por razones antojadizas de la Junta de Gobierno; cuando esta última se sentía amenazada, allanaban las casas y detenían a estos militantes. La vida en el penal, al menos del núcleo más selecto de comunistas y calderonistas, adquirió características especiales. Carlos Luis Sáenz nos dejó una valiosa información de sus experiencias en la prisión, la cual permite conocer detalles; a propósito de uno de los pabellones, dice:

Prácticamente pasamos el día en este espacio: leemos y dormimos en el salón; visitamos el otro (igual al nuestro) ocupado por el resto de amigos; comemos en alguna mesa rústica (mejor dicho, carcelaria), dispuesta a veces en el corredor o en el salón: el espacio se me amplía cuando bajamos al patio que limita con los jardines y huerto del penal. Y este es el espacio geográfico "que pretende" enmarcar nuestra vida. En semejantes condiciones trabaja afanosamente la sensibilidad pasando y repasando lo que los sentidos le muestran repetidamente. ${ }^{30}$

Escribe y lee mucho; dibuja, observa los diversos prototipos humanos para este intelectual la cárcel permitió sensibilizar todos los sentidos: lo que antes no veía, ahora logra o al menos intenta, descifrar, a partir de aquel encarcelamiento, monotonía, un tiempo que transcurre lentamente y permite sacar la fuerza del escritor, que produce un libro de poesía al tituló Con la pipa en la boca. En tono jocoso y satírico, escribe el poeta: "de mis poemas te informo he escrito los siguientes: 1) las paredes; 2) imaginaria; 3) sol; 4) inventario; 5) el pan nuestro [...]" ${ }^{31}$ Escribió un cuento y una copiosa correspondencia dirigida a su esposa, Adela Ferreto, y realizó numerosos dibujos que retrata de personajes y lugares del presidio.

30 Francisco Zúñiga, Carlos Luis Sáenz, San José de Costa Rica, 1991, (Colección Santamaría), p. 379. 31 Ibid., p. 381. 
También arregló versos escritos por otros presidiarios en alguna celda de aquella prisión:

Mis coplas voy a dejar

En esta cárcel doliente

Para que sepa la gente

De uno que vino a penar.

Al leerlas llorará

Viendo que sigue el camino

Por donde hube de pasar.

Y aqui ya queda mi historia

Escrita con mi dolor;

Yo soy una triste escoria

Del fuego de una pasión.

Y no quiero decir más

Porque soy hombre valiente;

Si de mí se rie la gente

Yo me río de los demás.

Con mi firma calzaré

Estas coplas de prisión:

Yo soy un pobre José

Y mi apellido es Muñoz. ${ }^{32}$

Por la copia

\section{C.L. Sáenz}

Una parte de su tiempo la dedicó a la enseñanza junto con Arnoldo Ferreto, quien dictaba clases de literatura; Luis Carballo ocupaba su tiempo en estudiar inglés y dibujar, mientras que

32 Ibid., p. 386.
Fernando Villalobos impartía clases de inglés. Con respecto a las mujeres, dijo:

Por otra parte, es necesario precisar la persecución y violencia con que el Tribunal de Sanciones Inmediatas trató a las mujeres comunistas y calderonistas, detenidas en la cárcel de mujeres El Buen Pastor, tales como: Pilar Bolaños, Luisa González, María Esquivel, Emilia Prieto Tugores, Mercedes Castillo de Palma, María Socorro Delgado vda. de Palma, Estela Peralta Escalante, Esther Vásquez, Rosario Solano Mata, María Josefa Esquivel Zapata, Corina Rodríguez de Cornik, María Alfaro, entre muchas otras acusadas de sedición $[\ldots]^{33}$

El mayor G. Martí, director general de detectives, envió un oficio al Tribunal de Sanciones Inmediatas, en que manifestó su empeño en hacer cumplir las leyes recién promulgadas, por lo que se arrestó a varias mujeres. Las detenciones comenzaron el 2 de agosto y se prolongaron varios días. Entre ellas se encontraban María del Socorro Delgado, Mercedes Castillo de Palma, Rosario Solano Mate, Estela Peralta Escalante, Emilia Prieto Tugores. Eran sindicadas en los mismos asuntos: por más que se

33 M. Barahona, op. cit., p. XXIV. 
empeñaron ellas en negar los cargos en concreto al practicárseles el registro se les encontraron folletines o periódicos amarillos de Trabajo y distintas clases de folletos y correspondencia en abundancia. Especialmente, todas ellas confirmaron haber sido simpatizantes de aquel partido, al cual apoyaron material e intelectualmente. ${ }^{34}$

Pasemos ahora al exilio comunista en México. La primera observación es un fenómeno mucho más limitado de lo que a veces se dice y se piensa; la particularidad más visible es que se trata del secretario general del PVP y que en él recaen muchas de las reformas sociales que vivió el país en los años cuarenta, se trata de Manuel Mora Valverde.

Las redes entre el Partido Comunista Mexicano y El Partido Vanguardia Popular costarricense se habían estrechado durante el decenio de los cuarenta, sobre todo bajo una política antifascista y antiimperialista adoptada por estas agrupaciones; no debemos olvidar que el Partido Comunista costarricense en los años treinta se opuso al líder mexicano Vicente Lombardo Toledano, al acusarlo de oportunista y reformista. En la década de los cuarenta, esas diferencias se habían limado, y el dirigente mexicano viajó a Costa Rica y ayudó a

34 Archivo Nacional, R 1660, f. 73 y siguientes. formar la Confederación de Trabajadores de Costa Rica (CTCR) desarrollando una política de amistad con todo el programa reformista que se desplegaba en Costa Rica; así comenzó una fructífera colaboración entre estas agrupaciones, y sus secretarios generales mantuvieron comunicación epistolar sobre diversos asuntos políticos y sociales; entre esa correspondencia, hay una petición desesperada a pocos días de finalizar el conflicto bélico en Costa Rica, donde el dirigente costarricense pide ayuda. Observemos esta súplica fechada el 11 de abril de 1948:

\section{Compañero Lombardo:}

El envío de armas es asunto vital para nosotros. Pero no cualquier envío, un envío. Sino un envío inmediato, porque nos estamos batiendo con las manos limpias. Ya intervino en la danza el Departamento de Estado. Ha impedido que otros gobiernos nos proporcionen armas y hasta estuvo planeando una invasión de la Guardia Nacional de Somoza que el Presidente Picado rechazó desde que le fue insinuado. Desde luego, todas las condiciones se resumen en la liquidación de Vanguardia Popular y de la CTCR. Los revoltosos han hecho saber oficialmente que sus 
fuentes son inagotables. Usted y nosotros sabemos cuáles son esas fuentes. En estos días desaparecieron dos aviones de la zona del canal, se trata de un robo misterioso que las autoridades yanquis no se explican. Pero hace la casualidad que en estos mismos días, los revoltosos han comenzado a operar con dos aviones y ya dejaron caer las primeras bombas sobre la casa presidencial. Nuestro caso es el mismo de España, en miniatura. Estamos luchando contra fuerzas internacionales muy grandes y hasta el momento nos sentimos solos. Le ruego interesarse por que nos lleguen rifles, tiros, granadas de mano, ametralladoras, lanzabombas. En último caso, lo que le sea posible conseguir. Si nos puede enviar algunos militares españoles, muy bien. Pero que sea todo rápido porque en pocos días estaremos peleando en la capital. ${ }^{35}$ (Firma Manuel Mora).

Se trata de una carta desesperada por conseguir armas para enfrentar el ataque a la capital que era inminente, y todo indica que el dirigente mexicano

35 Fondo Universidad Obrera (FUO). Vicente Lombardo Toledano. no estaba en condiciones de tramitar semejante petición, parece ser muy tarde, la guerra civil estaba en un momento muy avanzada para intervenir con semejante arsenal. En todo caso, lo que acá nos interesa es considerar la relación tan estrecha que mantenían ambos dirigentes para entablar este tipo de comunicación con equivalente petición. Junto a esta nota, el PVP hizo un esfuerzo mucho más directo: envió dos veces, durante el mes de abril de 1948, a uno de sus dirigentes más destacados y de confianza, Jaime Cerdas, a la ciudad de México con el objetivo de ponerse en contacto con Lombardo Toledano, secretario general de la CTAL, para conseguir armas y milicianos españoles; los contactos impidieron conversar con el presidente Miguel Alemán. ${ }^{36}$ Nada se pudo hacer, Cerdas regresó a Costa Rica y redactó una nota con Manuel Mora, que firmó el presidente Teodoro Picado para su homólogo mexicano. Este segundo viaje fue infructuoso, el argumento de Alemán era bastante contundente: si México era mediador en el conflicto costarricense, cómo iba a proporcionar armas a los comunistas. ${ }^{37}$

36 Jaime Cerdas, La otra vanguardia, San José de Costa Rica, EUNED, 1993, p. 161.

37 Ibid., p. 164. 
Lombardo Toledano se mantenía informado de la crisis política en Costa Rica por fuentes de primera mano del PVP, las cuales se confirmaban por medio de Rodolfo Guzmán, secretario general de CTCR, y que a fines del 48 se encontraba exiliado en México en trabajo político y sindical en una de las secretarías de la Confederación de Trabajadores de América Latina (CTAL).

Cuando las autoridades de Relaciones Exteriores de México preguntaron a su embajador Carlos Ojeda, el 27 de abril de 1948, sobre la situación de asilo político del costarricense Manuel Mora Valverde y otras personas, el funcionario envió la siguiente información a la ciudad de México:

Ministro de Seguridad Pública Brenes Gutiérrez trajo a esta Embajada de México personalmente al señor Manuel Mora Valverde y a la escritora Carmen Lira de nombre Isabel Carvajal y a su enfermera Judith Ferreto para cuidarla, con la súplica de concederle asilo, pues temían por sus vidas. De acuerdo con prescripciones establecidas, no tuve inconveniente en concederles asilo, máximo que el licenciado Mora ha tenido conferencias con el actual secretario de relaciones señor Figueres a través Presbítero Benjamín Núñez futuro ministro de relaciones exteriores, pues trátase de un elemento destacado del cual depende en gran parte la pacificación total de la República. Ellos han juzgado de conveniencia que asilados políticos abandonen provisionalmente el país por su seguridad personal, lo que harán mañana mismo y como han solicitado asilo en México los he documentado como turistas a fin de que posteriormente en secretaría queden en posibilidad resolver lo conveniente. Asimismo tengo asilados y saldrán a México con visa turística el director del periódico "última hora" Jorge Hernández, el juez Víctor Manuel Cañas Frutos, mismos fines. ${ }^{38}$ Ojeda

Las autoridades mexicanas instruyeron ese mismo día a Carlos Ojeda el modo en que debía documentarlos: "1. Por ningún motivo fundamentarlos como turistas pues primero Secretaría de Gobernación podría hacer responsable a usted por irregularidad en la documentación. 2. Corren peligro de no ser admitidos por la misma razón. 3. Turistas no pueden permanecer

38 Archivo Histórico Genaro Estrada de la Secretaria de Relaciones Exteriores de México (AHGE-SRE), exp. 19094, Correspondencia, San José de Costa Rica, 29 de abril de 1948. 
en México sino seis meses al fin de los cuales tienen que abandonar el país o son deportados 4. Esperamos salida de efectuarse completo acuerdo con autoridades costarricenses". ${ }^{39}$

La salida de Manuel Mora hacia México es explicada en una carta fechada el 24 de abril y dirigida al embajador Carlos Oje$\mathrm{da}$, donde sostiene que las autoridades costarricenses no le garantizan la vida, y pide el asilo en esa embajada por el tiempo necesario para definir su situación.

Ojeda comunicó al Secretario de Relaciones Exteriores, Gonzalo Facio, de la permanencia de Mora en su Embajada y expresó su solicitud y aceptación de asilo. El 29 de abril, Gonzalo Facio señala que esta Secretaría de Estado se halla en un todo conforme con la salida del país de las personas que se han acogido a esa Honorable Embajada, con motivo de los últimos acontecimientos políticos recientemente ocurridos, con garantías absolutas de sus vidas, desde luego, por parte del actual Gobierno de la República. Esta retórica argumentativa es contradictoria con una nota firmada por él sobre el mismo asunto, donde acepta que Mora busca el asilo político, por lo que el gobierno no da garantías de su seguridad personal.

39 Ibid., México, 29 de abril de 1948.
Cinco días después, Mora tomó un avión que le condujo a México, no sin antes agradecer al embajador la hospitalidad recibida, quien lo acompañó hasta el propio aeropuerto, ubicado en aquel entonces en La Sabana. La salida de Mora de San José fue dramática: "en sala de espera fue acompañado por Víctor Manuel Sanabria para resguardar su vida; aun así, sufre un último atentado antes de subir al avión "escoltado de policías, en el final de la pista, un grupo de excombatientes ametralló el avión al extremo de que en vez de dirigirse a México, cambió su destino original hacia Panamá."40

El exilio costarricense en México que se produce durante los años de 1948 a 1951, comprende especialmente el conformado por comunistas y, en menor grado, por calderonistas. Es de élite ya que está configurado en un primer momento por el secretario general del PVP, Manuel Mora Valverde, y por la escritora Carmen Lira y su enfermera, Judith Ferreto; luego se incorporó, ya en México, Claudia, hermana de Manuel para ayudar en el cuidado de Chabela, como le nombran sus más íntimas amigas y amigos. Posteriormente, se fueron sumando otros nombres relevantes dentro de la estructura

40 Addy Salas, Con Manuel, San José de Costa Rica, EUCR, 1997, p. 34. 
partidista, como: Rodolfo Guzmán, secretario general de la CTCR, y Eduardo Mora; en el año 1949 llegó Carlos Luis Fallas, quien permaneció varios meses; y también Rosita Braña, hija de Adolfo Braña, quien se casó con Raúl Castellanos, cuñado de Eduardo Mora, Adela Ferreto, Alfonso Mora, Carmen Paniagua, sus hijos Virginia, Carmen, Margarita y Jorge; además de Merino y Coronado; éstos se unieron a los costarricenses Eugenia Bermúdez Mora, Oscar Bermúdez Mora, Addy Salas, que se encontraban en México y viven el exilio acompañando solidariamente a sus coterráneos; asimismo estuviero el hermano de Carmen Lira y otros ciudadanos costarricenses, que deben llegar aproximadamente a 50 individuos, vinculados por diferentes lazos al Partido Vanguardia Popular o sus dirigentes.

Desde luego que esta primera aproximación es bastante limitada, ya que deja por fuera un porcentaje significativo de costarricenses que buscaron refugio en México, sobre todo calderonistas, incluidos el propio Calderón Guardia y su familia. Por razones de espacio no podemos abarcar con mayor profundidad este fenómeno.

En octubre de 1949, se abrió expediente en el Ministerio de Relaciones
Exteriores de México, ante la presunta conspiración política en dicho país en contra del gobierno de Costa Rica. La Hora y el Diario de Costa Rica desplegaron amplia información al respecto. En ella señalan al menos a Julio López Masegoza y a Jacobo Fernández (Fernando Alberdi Ysarragorrei) como presuntos instigadores; involucran al general Lázaro Cárdenas y a Ignacio Beteta, entre otras personalidades. De inmediato el gobierno mexicano reaccionó a través de su embajador en San José, Manuel de Negri, quien en comunicado oficial negó cualquier movimiento de carácter revolucionario en contra de Costa Rica y declaró que esta idea carecía de fundamento y que su gobierno mantenía los principios de no intervención y de respeto a los tratados internacionales. Dichas declaraciones fueron publicadas en el Diario de Costa Rica el 27 de octubre de 1949.

La posición oficial del gobierno mexicano, efectivamente, era de no intervención en asuntos de otro país, aunque es bastante probable que exiliados costarricenses caldero-comunistas usaran las condiciones que brindaba México para sus actividades políticas, incluidas las de entrenamiento militar, para una posible invasión a Costa Rica. Uno de éstos era Julio López 
Masegoza, ${ }^{41}$ piloto republicano, que meses antes había visitado a Manuel Mora para trasladar a Carmen Lira en viaje clandestino vía aérea a Costa Rica, viaje que no se realizó debido al fallecimiento de la escritora costarricense. ${ }^{42}$

En circunstancias de exilio, Manuel se encontró con Addy Salas y profundizaron su amistad y amor, hasta consumarse en matrimonio en esos años; fue su compañera, y con ella vivió aspectos íntimos de su exilio mexicano. La colonia donde residió Manuel Mora, en la ciudad de México, era Atenor Salas, barrio nuevo y solitario; en esa casa también estaban Chabela y Claudia.

Mora debió continuar con sus tareas partidistas y su vida privada parecía ir tomando forma; la relación con Addy Salas continuó; y eran; salían cada vez que podían a caminar y correr la ciudad, sus avenidas y parques, en donde platicaban y creció el amor entre ambos:

41 Según fuentes mexicanas, este personaje era un aventurero español, exiliado en México, el cual se autoproclamaba dirigente para alentar revoluciones en el continente, habiendo tomado parte en expediciones contra el régimen dominicano, y ahora pretendía encabezar el derrocamiento de Otilio Ulate y dirigía el adiestramiento de paracaidistas costarricenses. También conocen en México los movimientos de Rosendo Arguello hijo quien organizaba otro alzamiento contra régimen en Nicaragua. Se decía que Masegoza había comprado un par de aviones para tal efecto. SRE, México, DF, 23 de octubre de 1949.

42 Véase A. Salas, Con Manuel, op. cit., p. 35.
Lo invité a caminar uno de aquellos días por la avenida La Reforma para visitar los eucaliptos del Parque de Chapultepec; me gustaban mucho en cualquier tiempo, por el olor, pero especialmente en aquellos meses de septiembre y octubre, sus copas cobrizas desprendiéndose de algunas de sus hojas más maduras, $\mathrm{y}$ el sol, el sol por todo, como lluvia finísima de material resplandeciente, se adhería a las calles y a los edificios, subía alto en el aire. ${ }^{43}$

Manuel Mora la llevaba a donde quiera que iba, a donde los Calderón, al palomar, al BIP, ella le ayudaba en la corrección de algún artículo, buscaba algún dato; luego juntos dejaban los trabajos y también cobraban; luego de terminados los estudios Addy pasaba por él a las reuniones partidistas, todos los camaradas mexicanos comenzaron a conocerla. Mora no aceptó ayudas económicas ofrecidas por Lombardo Toledano y el propio Partido Comunista Mexicano; por el contrario, se ganaba la vida escribiendo para algunas revistas y boletines de temas económicos y políticos; seguramente la beca de la que gozaba Addy. El Colegio de México alcanzaba para cubrir ciertas necesidades de ambos.

43 Ibid., p. 147. 
Otro apoyo con el que siempre contó Manuel Mora fue su hermano Alfonso, abogado, que laboraba en un banco y radicaba en la ciudad de México, acompañado de su familia.

Manuel Mora pasaba muchas horas con Carmen Lira, y desde la cama ella le dictaba a él su novela En una silla de ruedas, para una segunda edición sin recortes del editor. La salud de la escritora empeoraba, por lo que Mora se comunicó con personeros del gobierno pidiendo el regreso a Costa Rica, petición que fue denegada. Carmen Lira muere en México el 14 de mayo de $1949 .{ }^{44}$ Eran pocas las personas que la visitaban; por las mañanas se sentaba frente a una ventana a tomar el sol, bien arregladita, con toda su coquetería; conversaba con Manuel y Addy, de modo intermitente recibía la compañía de Yolanda Oreamuno, Vicente Sáenz y algún otro visitante distinguido como Diego Rivera. La muerte de la escritora es un golpe muy duro para Mora. De inmediato, sus camaradas mexicanos expresaron sus condolencias en un mensaje que

44 Ibid., p. 37. "Addy Salas, recuerda haber escuchado a Manuel Mora de intentar traer a Carmen Lira para que muriera en Costa Rica; lo haría en un avión clandestino piloteado por Julio López Masegoza (miliciano republicano), quien se ofreció para esa misión, Mora iría maquillado y disfrazado como médico, junto a la camilla en donde viajaría la escritora; pero la muerte llegó antes de completarse el plan”. recoge la atmósfera de aquellos días fatídicos de la costarricense:

La violencia política trajo a Carmen Lira hasta México. Arrancada de su pueblo y de su tierra, como acto final de una serie de hondas conmociones que sufriera la gran escritora de Costa Rica, vivió en México siempre llena de angustia por la muerte de los suyos y por los acontecimientos dramáticos que se han desarrollado a lo largo de nuestro Hemisferio.

Enferma aquí y la ciencia fue inútil para salvarle la vida, su último deseo era el de morir en su patria; pero ni esto siquiera fue dable.

Los pueblos de habla española en el mundo y especialmente los de América Latina, pierden en Carmen Lira a uno de los valores más altos y finos espíritus de nuestro tiempo. Escritora brillante, poetiza profunda, maestra extraordinaria, mujer ejemplar, brillante, militante inapreciable de las causas más elevadas de la América Latina, deja un sitio que muy pocos pueden ocupar, pero también deja una senda llena de luz para nuestros varones de 
América. Y también una obra que no ha de extinguirse sino que con el tiempo ha de crecer, porque parte de ella se renueva cada año en todos los países de América latina, en los cuentos maravillosos que ella contó para todos los niños actuales y futuros de todas partes. Carmen Lira es una víctima de la violencia desatada en contra de los mejores espíritus en estos días aciagos para las libertades de América Latina.

Pero las fuerzas que en todas partes se robustecen, a pesar de todos los obstáculos, las fuerzas renovadas del pueblo rendirán oportunamente homenaje no solo en Costa Rica, sino en todos nuestros países, a quienes supo hacer bandera de su propia vida, bandera de la causa más noble y más grande: la emancipación de nuestros países, de las fuerzas retrógradas de adentro y de afuera.

Firma. Comité Central de la CTAL, 16 de mayo de 1949, Vicente Lombardo Toledano, presidente, Agustín Guzmán, Pedro Durán, Rodolfo Guzmán, Roberto Morena, Salvador Ocampo se- cretarios, Enrique Ramírez y Ramírez, Auxiliar de secretariado ${ }^{45}$.

María Isabel Carvajal salió de Costa Rica no por un decreto-ley que la expulsara de su país; fueron historicidades mucho más profundas de aquellos años que condujeron a la guerra, un protagonista de época lo interpreta así:

De ese caos, de esa tragedia y de ese infierno creado por la apatía de unos y la complicidad criminal de otros-salió nuestra querida Carmen Lira una mañana en un avión que recibió los impactos de los rifles entregados al desenfreno. Venía herida, de muerte, escapando a la saña de quienes- de ello estoy dolorosamente convencido- sin respetar personalidad ni su dolencia, le habrían sumido en una bartolina inmunda apresurando el fin de sus días, escarnecida y humillada. ${ }^{46}$

Carmen Lira fue sepultada el domingo 22 de mayo de 1949 en el Cementerio General en San José; miles de personas le acompañaron, a pesar de que la prensa nacional casi no lo menciona; sólo

45 FUO, Vicente Lombardo Toledano, correspondencia, 16 de mayo 1949.

46 Albertazzi Avendaño, op. cit., p. 93. 
un par de pequeñas esquelas entre avisos sociales que decían escuetamente: "Carmen Lira ha muerto en la ciudad de México. Sus restos llegaron a las 7 de la mañana del día 20 de mayo. El cuerpo permaneció en su casa de habitación en capilla ardiente. Hasta el domingo 22 de mayo cuando se efectuó el funeral luego de una misa por la mañana para pasar al Cementerio General.”

La Nación, del martes 17 de mayo de 1949, publicó los mensajes cruzados entre Manuel Mora y José Figueres, provocados por la muerte de María Isabel Carvajal, que muestran las tensiones entre ambos. Dejemos en extenso esta documentación que habla por sí sola: Mora escribe desde México el 14 de mayo de 1949.

\section{A José Figueres, Casa Presidencial.}

Carmen Lira ha muerto. Usted la conocía muy bien y me conoce a mí. Su conciencia ha debido decirle siempre que ni ella ni yo somos autores de los crímenes que ha querido atribuirnos la propaganda perversa de los verdaderos enemigos del pueblo de Costa Rica. A pesar de eso, entiendo y acepto lo que se ha hecho y pueda hacerse contra mí, pero no puedo aceptar la ini- quidad desplegada contra la mujer más noble y más valiosa que ha producido nuestro país. Iniquidad llevada al extremo de no permitirle pasar en su patria las últimas horas de su vida. Sobre su conciencia y sobre sus colaboradores gravitará siempre este crimen cometido en perjuicio de una persona ilustre no de un partido, sino en perjuicio de una nación y de la cultura universal. MMV.

San José, C.R. Mayo 16

Señor Manuel Mora

México D.F.

Comprendo que la exaltación de su ánimo, lógica en momentos para usted tan dolorosos, como los que debieron significar la muerte de una leal y abnegada colaboradora suya, lo haya determinado a imputarme un crimen que no cometí. La Junta de Gobierno que presido nunca negó a Carmen Lyra su ingreso al país y personalmente le indiqué, por conducto de Vicente Sáenz, de quien recibí gestiones directas en favor de ella, que no ponía objeción a su deseo de volver a Costa Rica. Pero que por el estado de emergencia que entonces vivía el 
país con motivo de la invasión, le aconsejaba, para su propia seguridad, no hacerlo inmediatamente. De las protestas de inocencia suyas, nada puedo decir, porque será la opinión pública ahora y mañana, y el juicio de la historia quienes viertan su verdadero veredicto. JF.

Este cruce de cartas tan precisas y contundentes en acusaciones de uno y otro sobre un asunto tan delicado como fue la muerte de la escritora en México y no en su país natal, nos lleva a las siguientes consideraciones. En primer término, dos posiciones en tensión; al respecto, Manuel Mora Valverde hizo esfuerzos y empeños de todo tipo para que Carmen Lira pudiese regresar en vida a Costa Rica, al punto de fraguar un viaje aéreo clandestino para transportar a Lira, cuestión que no se produjo porque a Lira le alcanza la muerte; por su parte José Figueres es contundente en cerrar las puertas a la escritora argumentando un motivo de inseguridad y la invasión; hoy sabemos que la escritora siempre tuvo su intención de retornar a su país antes de morir, y en su última carta escrita desde la ciudad de México, fechada el 9 de marzo de 1949 (dos meses antes de su muerte), entre otras cosas, expresa su deseo y añoranza de reunirse lo más pronto posible con sus seres más queridos. ${ }^{47}$

47 Excélsior, 1 de agosto de 1976, p. 4.
El cierre de la nota de Figueres nos lleva a otro terreno más movedizo. Dice el jefe de la Junta de Gobierno "de las protestas de inocencia de Mora", así que no lo exonera, sino más bien lo envía a juicio, esta vez al tribunal de la Historia con mayúscula, apelando de este modo a una acepción de la historia como moral, como una especie de personaje mítico emitiendo sus propios juicios, con lo que se podría prescindir de todo tipo de análisis. ${ }^{48}$ Pasado más de medio siglo, podría interpretarse, basados en la historia, que Mora fue absuelto y que Figueres, por el contrario, ha sido ubicado en su contexto como un personaje que no solo no dejó entrar a Carmen Lira en vida sino que actuó con mano fuerte y violenta contra sus adversarios políticos.

El domingo 22 de mayo, el Diario de Costa Rica, en coincidencia con su funeral, publicó un poema dedicado a "Carmen Lira", cuyo autor podría ser el reconocido escritor costarricense autoexiliado en México, Vicente Sáenz:

Enclavada en la cruz de la nostalgia

Tu pobre corazón languidecía

$Y$ se agolpaban en tu sien las penas

Como dardos punzantes, como espinas

Más también a tu cruz por darte alivio

48 Véase Pierre Vilar, Iniciación al vocabulario del análisis histórico, España, Editorial Crítica, 1980, pp. 19-21. 
Llegaban como tristes golondrinas

En bandada de inquietas esperanzas

Las fraternales almas que sufrian...

¿Sentiste alguna vez sobre tu frente

Que la fiebre abrasaba y consumia,

El enorme abanico de las olas

Que junto a ti batian las golondrinas?

¿Sentiste la caricia de sus picos

Sacando enternecidas las espinas

Para ceñir en la sangrante huella

Las hojas de laurel y siempre vivas?

Duerme en paz. Descansa "Carmen Lyra"

Que tu alma buena con virtud sencilla Regó sin egoísmo la semilla

Que había en tu corazón.

V.S.

El 23 de mayo de 1949, un grupo de compatriotas de Carmen Lira, desterrados y exiliados en la ciudad de Guatemala, brindaron un sentido homenaje, a ellos se sumaron la Confederación de Trabajadores de Guatemala (CTG), el Sindicato de Trabajadores de Educación de Guatemala (STEG), la Asociación de Juventudes Democráticas AJD, así como intelectuales. El acto fue trasmitido por radio y muchos costarricenses pudieron escucharlo. El costarricense exiliado Francisco Montero Madrigal leyó dos telegramas; uno de Enrique Muñoz Meany (ministro de Relaciones Exteriores) y otro del presidente del Congreso Mario Monteforte Toledo.
En ese homenaje participaron personalidades de las letras de varios países de Centroamérica y del Cono Sur: el nicaragüense Armando Amador, la profesora chilena Virginia Bravo Letelier, la poetisa salvadoreña Matilde Elena López, los guatemaltecos Víctor Manuel Gutiérrez, Ester Merino de Montejo el doctor Mariano Padilla y el costarricense José Albertazzi Avendaño, quien en un largo y profundo discurso destacó la labor de la costarricense como escritora y luchadora de las causas más justas en favor de los que más lo necesitan. ${ }^{49}$

Manuel Mora Valverde, en México, pasó mucho de su tiempo en tareas políticas, especialmente aquellas relacionadas con sus vínculos con las organizaciones partidistas presididas por su amigo y presidente de la CTAL Vicente Lombardo Toledano, quien había desarrollado una política de alianza y amistad no sólo con el dirigente comunista, sino también con Calderón Guardia, a quien desde inicios de los años cuarenta expresaba su admiración por impulsar las reformas sociales a los trabajadores de su país como un ejemplo para el resto de América Latina.

Lombardo Toledano lo inició en los círculos comunistas, y progresistas de la capital mexicana; incluso envió una

49 Albertazzi Avendaño, op. cit., p. 85. 
carta a Lázaro Cárdenas, presentando a Manuel Mora como uno de los hombres más importantes por la lucha social en el continente.

Uno de los aspectos menos conocidos del exilio del dirigente comunista Manuel Mora Valverde es cuánto tiempo permaneció en México; si bien es cierto que desde 1948 intentó regresar, todo indica que no fue, al menos, hasta 1950, posiblemente entre marzo y julio, cuando regresó a Costa Rica.

Entre 1948 y 1949, Manuel Mora apareció de incógnito en Guatemala, seguramente en tareas políticas, y llevó a cabo conversaciones con personalidades del gobierno y exiliados costarricenses.

Hablemos del regreso de Mora, llegado en el mes de marzo de 1950. La CTAL organizó una cena de despedida al dirigente costarricense, que tuvo lugar en el "Centro Vasco" (Madero número 6), en la ciudad de México, el miércoles 1 de marzo de 1950, a partir de las 21 horas. Hicieron uso de la palabra Vicente Lombardo Toledano, presidente de la CTAL, el profesor Raúl Cordero Amador, costarricense radicado en México, y el dirigente chileno César Godoy.

Los discursos estaban marcados por un mensaje antiimperialista y contra la política belicista implementada por Estados Unidos luego de la Segunda Guerra Mundial, y la privación de los derechos del hombre. En uno de ellos se lee: "[...] no regresa Manuel Mora a su Patria confiado al azar o a una benevolencia de las autoridades de su país, sino que regresa por mandato del pueblo; por derecho propio de costarricense, también por la urgencia de contribuir a salvar los intereses profundos de nuestros pueblos en esta hora difícil."

La reunión tenía como propósito político alertar al gobierno de Costa Rica de que si algo le pasaba a Manuel Mora, lo harían responsable, junto con los agentes del imperialismo. Prepararon un documento firmado por varias personalidades continentales, entre las que destaca el chileno Pablo Neruda; se exhortaba a tener presente siempre "que usted será uno de los generales, de los líderes de la batalla común de nuestros pueblos; que a su lado, muy próximo a usted y a los suyos se hallan otros combatientes por los mismos principios." 51

50 Fondo Universidad Obrera (FUO) Vicente Lombardo Toledano. Versión en taquigrafía de los discursos pronunciados en la cena de despedida del dirigente popular costarricense MMV, 1 de marzo de 1950 , p. 3.

51 Ibid., p. 8 . 
Cordero Amador destacó las cualidades del dirigente, como un intelectual que piensa y hace lo que dice, de su honestidad puesta a prueba durante toda su vida. Recordó la lucha antiimperialista costarricense que se inició entre 18561857 contra los filibusteros. Por su lado, César Godoy habló en representación de otros exiliados de otros países hermanos que vivían en México y también en nombre de los compañeros de ideología de Manuel Mora (chilenos).

La cena no era alegre sino llena de una atmósfera de tristeza sobre todo por la responsabilidad del momento: "decimos Al gobierno de Costa Rica, que Manuel Mora se reintegra después de dos años de limpio exilio a su país, rodeado de la estimación de muchos hombres que ven en él toda una bandera y todo un símbolo en la lucha antiimperialista y por la liberación de continente."

El mismo grupo redactó una carta con fecha 9 de marzo de 1950, dirigida a don Otilio Ulate Blanco, casa presidencial, San José.

En los siguientes términos: como viejos admiradores del pueblo de Costa Rica y de sus tradicionales instituciones democráticas hemos visto con sincero pesar el eclipse que esas instituciones han venido sufriendo en los últimos dos años.

Sin embargo, el hecho de que Costa Rica haya retornado a la vida institucional y el de que usted, como Presidente de la República, haya manifestado su decisión de no apartarse de las normas democráticas para gobernar, hacen renacer nuestra esperanza de que esa nación vuelva a ser lo que fue: país respetuoso de los derechos individuales y colectivos de los ciudadanos.

Nos permitimos hacer estas manifestaciones con motivo del regreso a su patria del Lic. Manuel Mora Valverde, después de dos años de exilio en México. No dudamos que gozará de garantías bajo su gobierno, a pesar de los rumores que circulan sobre posibles atentados contra su vida. Saludan atentamente al señor Presidente.

Vicente Lombardo Toledano, Pablo Neruda, acompañan una veintena de firmas. ${ }^{52}$

52 FUO, Vicente Lombardo Toledano, correspondencia del 9 de marzo de 1950. 
Queda claro que el regreso del líder comunista era unasunto de tal importancia que se hacía declaratorias continentales desde México para cubrir dicho viaje de cualquier atentado; es de suponer que la vida de Mora corría peligro.

Paralelo a este acto de despedida y regreso a Costa Rica debemos considerar otro hecho significativo que hacía forzoso su regreso. Addy Salas estaba embarazada del que sería su primer hijo, Manuel Mora Salas, quien nacería en San José el 29 de julio de 1950. Años más tarde en un discurso de 1958, luego de diez años de no usar un medio de comunicación costarricense, recuerda: "en el año 1950, con motivo de unas bombas que estallaron en la capital, Ulate, ya Presidente, ordenó que se me hiciera preso [...] se me puso en una celda con los reos comunes [...]" ${ }^{\prime 3}$

Entre aquella despedida en ciudad de México, en marzo a junio de 1950, fue cuando Mora regresó a Costa Rica y recibió el mismo trato que otros comunistas del país. A comienzos de agosto de ese año, Manuel Mora y otros comunistas fueron sido encarcelados sin motivos claros; ${ }^{54}$ era

53 Manuel Mora. Discursos, 1934-1979, San José de Costa Rica, Editorial Presbere, p. 233.

54 La Hora de 17 de julio de 1950, dice: "Los comunistas de Cuba pidieron la libertad de Manuel Mora”; el cable estaba firmado por Juan Marinello y Blas Roca. un periodo de persecución. En tono jocoso, Jaime Cerdas relata: "nos dejaban salir de la cárcel y luego nos volvían a apresar. Yo acostumbraba acostarme vestido [...] pasábamos más rato adentro de la cárcel que afuera." ${ }^{25}$

Eduardo Mora Valverde, hermano de Manuel, hizo un periplo un tanto distinto. Pasada la guerra civil de 1948, salió del país, en mayo de ese año, y se dirigió a México, que no le era ajeno, pues allí había permanecido varios años desde 1943, e inicío estudios de economía en la Universidad Nacional Autónoma de México (UNAM). Su labor política puede calificarse como intensa en diversos frentes de organización, en la propia universidad, como de carácter continental; en una etapa caracterizada por la lucha antifascista, fue representante de los jóvenes comunistas de la UNAM. Enfrentando la corriente browderiana dentro del Partido, que había terminado con las células en escuelas y facultades, las responsabilidades en el PCM crecían y se le nombra responsable del trabajo con los estudiantes.

Trabajó en "La voz de México", por lo que recibió una pequeña remuneración. Preparó informes, escribió para la revista Tiempo, con lo que mejoró

55 J. Cerdas, op. cit., p. 167. 
su situación económica. ${ }^{56}$ En el año de 1944 viajó urgentemente a Costa Rica, debido a la enfermedad de su madre. Regresó de nuevo a México en 1945, en donde redobló su trabajo en el PCM y viaja por toda la república mexicana en labores políticas.

En una fiesta organizada por Diego Rivera, entre 1948 y 1949, Eduardo conoció a Elena Castellanos; formaron un hogar en medio del trabajo partidista en el exilio. Elena queda embarazada a finales del 1950 y se trasladó a San Salvador; al poco tiempo, llegó Eduardo a El Salvador para ayudar en la construcción orgánica del Partido Comunista Salvadoreño. ${ }^{57}$

Al poco tiempo, comenzó una serie de detenciones, maltrato y torturas en Honduras, El Salvador, hasta que pudo regresar a Costa Rica en 1952, gracias a las intervenciones del presidente de la república, don Otilio Ulate y del monseñor Sanabria ante las autoridades centroamericanas. $\mathrm{Al}$ llegar, la Dirección Nacional del Partido Vanguardia Popular lo puso al frente del Comité Regional de San José y lo designó representante del partido ante el comité Nacional de Partidarios por la Paz, cuyo presidente honorario era don Joaquín

56 Eduardo Mora Valverde, De Sandino a Stalin, San José de Costa Rica, Editorial Revolución, 1988, p. 83.

57 Véanse las actividades clandestinas desarrolladas por Eduardo Mora, Ibid., pp., 133-136
García Monge. Se integró al Secretariado Ejecutivo junto a Manuel Mora, quien era conocido con el nombre clandestino de Jacinto Carvajal, norma que usaban todos los miembros de esa Comisión.

En una carta enviada desde Pekín, el 20 de octubre de 1952 y dirigida al presidente de la república de Costa Rica, por una enorme cantidad de intelectuales latinoamericanos, se lee:

[...] su protesta por la acusación que ante los Tribunales de Justicia de Costa Rica, ha interpuesto la Procuraduría de su Gobierno contra el Sr. Eduardo Mora Valverde por el hecho de trabajar activamente en el movimiento de la paz, que sin banderías políticas ni sectarismos ideológicos, se opone a las agresiones de una nación contra otra, se opone a la crueldad de la guerra bacteriológica y van a llevar a los hombres a otra hecatombe mundial $[. . .]^{58}$.

La situación de Eduardo Mora pareció no mejorar con su llegada a Costa Rica, si la comparamos con lo ya sufrido meses antes en varios países de Centroamérica. En el final de la carta anterior en manuscrito se dice que ese 20 de octubre

58 Archivo Nacionales. Fondo MMV, signatura 2527. 
ingresaba a la cárcel -como producto de una acusación- como militante del Partido Comunista Costarricense, como miembro del Consejo Mundial de la Paz y como traidor a la Patria, y el 5 de marzo de 1953, de nuevo estaba en la cárcel.

\section{Conclusiones}

Los acontecimientos armados de 1948 han sido mayoritariamente presentados por los vencedores desde ese cómodo espacio que da el poder, y como pensamiento oficial han sido difundidos y consumido masivamente entre los costarricenses, que en algunos casos, por conveniencia han callado sus voces por el temor a ser sindicados como enemigos de la democracia.

Hemos intentado, en este ensayo, alumbrar una importantísima veta investigativa que merece atención especial, como es la violencia desmedida y medida con la que actuaron unos costarricenses contra otros costarricenses por el solo hecho de no pensar y actuar del mismo modo.

No se trata de incriminar una versión u otra; interesa develar los hallazgos propios de un proceso particular, tal es el caso del exilio costarricense a México y otras repúblicas del área, donde buscaron refugio cientos y miles de costarricenses de los llamados caldero comunistas. Fueron, como lo hemos podido demostrar, el sujeto más perseguido durante los años de estudio y seguramente pasados éstos.

Violencia en todos los grados de la existencia humana, intencionalmente manejados a conveniencia, invisibilizando por años las injusticias cometidas contra un grupo de costarricenses que fueron fusilados, encarcelados, torturados física y sicológicamente, destituidos de sus puestos de trabajo, exiliados; pero el más grande fue el que estaba constituido por esos miles de costarricenses, que sufrieron el insilio como una herramienta desmovilizadora y criminal usada contra los vencidos y que tuvieron -como lo muestran los testimonios y los estudios efectuados-, que vivir no sólo al margen de la ley, sino, y lo más grave, al margen de los derechos por los que habían luchado.

Sin embargo, es necesario resaltar que fueron los comunistas desde la cárcel y en la clandestinidad, el exilio, el insilio y otras formas de exclusión quienes iban construyendo un día sí y otro también, la democracia costarricense, luchas que giran en torno a la igualdad de derechos electorales, independientemente de las convicciones ideológicas, pero ante todo de la defensa de las conquistas de los trabajadores de la ciudad y del campo en su conjunto. 
Si bien se pudieron obtener importantes documentos relativos a los acuerdos de la embajada de México, que constituyen la base del Pacto de Ochomogo, los cuales están firmados por el padre Benjamín Núñez en representación de José Figueres, comandante en jefe del denominado Ejército de Liberación, también se evidencia que entre Mora y Figueres habría surgido una serie de acuerdos, que afloraban como una potencial alianza entre estas dos fracciones otrora enemigas a muerte, que pretendían ampliar las garantías sociales y el código de trabajo, pero que en el marco de la Guerra Fría y el trabajo de los agentes del imperialismo, terminarían por crear una brecha entre esos actores y habrían truncado el plan de continuar profundizando el Estado social de derecho surgido en las décadas de los cuarenta y la lucha contra las dictaduras en la región .

Son ésos elementos los que van a seguir gravitando en el interior del Partido Comunista hasta que finalmente las contradicciones no resueltas terminan en la división del partido más antiguo de Costa Rica, ese que en el pasado logró una unidad con base en un proyecto país, en una inusual alianza con la Iglesia y un sector de la burguesía, pero que no tuvo la capacidad para mantener la unidad interna.
Este trabajo invita a incursionar profundamente en la vastedad de información por descubrir consultar e interpretar con el fin de contribuir, a develar una realidad que sigue siendo una cuestión en debate sobre aquellos acontecimientos, protagonistas y procesos que se mueven entre un pasado-presente.

Es evidente que el anticomunismo ha sido parte del utillaje de la mentalidad de los sectores dominantes costarricenses, como un recurso descalificador que prevalece aún hoy día, y es parte del imaginario nacional, siendo empleado en el discurso oficial, desde la opacidad del poder, dejando claro que se ha intentado borrar de la historia nacional la criminalidad de la posguerra, a conveniencia de los grupos que han tenido el poder, como un acuerdo entre pares que al judicializar la revancha llevaron a un estadio de indefensión a cientos y miles de costarricenses.

Por último, el acercamiento al fenómeno del exilio nos lleva a planteamientos de carácter más regional que nacional; se nos presentan como procesos con muchas aristas que se desarrollan fuera de las fronteras estrictamente del país que estudiamos. 
En el caso que nos ocupa, se hace urgente efectuar estudios detallados para completar los análisis de países como Nicaragua, Panamá y Guatemala, y así continuar y profundizar en el caso de México. De igual modo, se nos plantea el reto de emprender estudios sobre el insilio, como una cuestión urgente para poder captar esta otra forma de exilio que nos permita dimensionar el fenómeno desde su dimensión más humana, más íntima, familiar incluso. 